\title{
Organizational Culture and Leadership, Influence to Employee Engagement in Z Generation
}

\author{
Dian Kristiana Suryaningrum ${ }^{1}$, Billy Tunas ${ }^{2}$, Corry Yohana ${ }^{3}$ \\ \{dian_kars@yahoo.com ${ }^{1}$, tunasbilly@gmail.com², corryyohana@unj.ac.id ${ }^{3}$ \} \\ ${ }^{1}$ Doctoral Program in Human Resource Management, Universitas Negeri Jakarta, \\ Jl. Rawamangun Muka, Jakarta 13220, Indonesia \\ ${ }^{2}$ Postgraduate, Universitas Suryadarma, Jl. Angkasa, Halim Perdanakusuma, Jakarta 13610, Indonesia \\ ${ }^{3}$ Departement of Economics, Universitas Negeri Jakarta, Jl. Rawamangun, Indonesia
}

\begin{abstract}
In this digital era, many companies find it difficult to maintain their employees. Because the new generation has entered the workforce, commonly called the Gen Z. Unlike the previous generation who were more concerned with establishment, most of these generations were more concerned with rewards and considered social life as an important aspect. Various technological advancements, and consumptive behavior, are closely related to the characteristics of this millennium era. The purpose of this study is to analyze the influence of organizational culture and leadership on Employee Engagement. This research was conducted at Life Insurance Company, using path analysis methods in testing hypotheses. The sample in this study was 399 people with simple random sampling. The results of this study are: (1) Organizational Culture has a positive direct effect on Employee Engagement. (2) Leadership has a direct positive effect on Employee Engagement. The results of this study have implications for the influence of organizational culture and leadership that can support employee engagement in $\mathrm{Z}$ generation.
\end{abstract}

Keywords: Organizational Culture, Leadership, Employee Engagement

\section{Introduction}

To deal with intense competition in the current era of globalization, companies must maintain the assets they have in order to be able to handle the competition. One asset that is not free from attention is human resources in a company. The entry of the millennial generation into the largest workforce in Indonesia has become a challenge so special treatment is needed to maintain loyalty to the company.

Recognizing the importance of human resources, organizations must be able to manage and utilize the potential of their human resources. Managing here can be either applying the existing organizational culture properly. Culture as a pattern of basic assumptions that are created, discovered, or developed by certain groups when learning to deal with problems of external adaptation and internal integration that have run well enough to be considered valid, and therefore that, to be taught to new members as the right way to perceive, think and feel in connection with the problem at hand [1]. 
The success of a company to implement aspects or values of the company culture depends on the way of leadership in the company. Leadership: "leadership is defined as the process by which individuals influence others in ways that help achieve groups or organizational goals which means that leadership is a process of influencing other people in order to achieve group goals or organization goals [2].

To be able to realize engagement, we need a leader role in the organization. Employee relations with leaders will have a direct impact on the desire to stay working in an organization. Leaders that are supportive to their employees' career and individualdevelopment for each employee will be an important factor for employee loyalty. Therefore, leaders in organization must be observant to see employee satisfaction. If employee satisfaction has reached the highest level, employee engagement will arise.

Employee engagement is one way to make employee have high loyalty, as in the opinion of Macey and Scheider, which states that employee engagement makes employee has higher loyalty, thereby reducing the urge to leave the company [3]. Employee engagement is a condition of employee who is directly connected psychologically with his/her work. Employees will be connected physically, cognitively, or emotionally while showing their performance at work. Employee engagement is a method of working that is designed to ensure employee will be committed to the goals and values of his/her organization, motivated to contribute to the success of the organization, and at the same time will encourage employee's potential to achieve high performance.

In insurance companies, the highest turnover rate is come from sales. Most employees felt not engagement which meant that the employee might be productive but not feel psychologically bound. These employees tend to be less than optimal at work and have the potential to resign from the Company. Therefore, based on the background and the problem, a study was conducted on "The Influence of Organizational Culture and Leadership on Employee Engagement in the $\mathrm{Z}$ generation.

\section{Theoretical Study}

\subsection{Organizational Culture}

According to Colquitt, organizational culture is ". . . as the shared social knowledge within an organization regarding the rules, norms, and values that shape the attitudes and behaviors of its employees. "As knowledge that is accepted by people or community considering the rules, norms, and values organizational values which then shape the attitudes and behavior of employees [4]. Organizational culture according to Wibowo is that the organization's basic philosophy that contains shared beliefs, norms, and values that are the core characteristics of how to do something in the organization [5]. These beliefs, norms and values become the grip of all human data sources in the organization in carrying out their performance. From various definitions put forward by several experts, it can be synthesized that organizational culture is a system of value that is perceived as the glue of the organization so as to shape the attitudes, habits and behavior of all employees in an organization.

\subsection{Leadership}

Ivancevich et al. stated the definition of leadership as follows: "Leadership is an attempt to use influence to motivate individuals to accomplish some goals" [6]. Based on that definition, it can be defined that a leadership is an effort to use influence to motivate people in order to achieve goals. Another meaning of the definition is that leadership is related to the 
importance of leaders as change agent, namely that leaders can influence the behavior and performance of subordinates or followers in order to achieve common goals. Effective leaders have leadership competencies and will be able to realize success in the organization they lead.

Likewise, according to Shane that "leadership is about motivating, and enabling others to contribute to the effectiveness and success of the organization that they become members" [7]. The purpose of the statement is that leadership is a capability to motivate and persuade others to contribute to the effectiveness and success of the organization.

According to Goestsch and Davis, "Leadership is the ability to inspire people to make a total, willing, and voluntary commitment to accomplishing or exceeding organizational goals" [8]. That means a leadership is the ability to inspire people to make total, willing, and voluntary commitments to achieve or exceed organizational goals.

Based on the concepts described above, it can be synthesized that leadership is an art to influence, coordinate (harmonize / synchronize), motivate, mobilize, and support others to contribute towards achievement through the process of interaction and communication between leaders and employees, with dimensions to influence, coordinate, mobilize, support, and service success.

\subsection{Employee Engagement}

Kahn in Albrecht describes a theory of relationships and involvement that occurs closely physically, cognitively and emotionally between a person and his job role, which is then called as employee engagement [9]. In line with the definition above, Federman views employee engagement as a level where a person has committment to an organization so that it can determine how a person behaves and how long he or she will stay with that position [10].

According to Marciano, a worker who is engage will commit to the goal, use all his abilities to complete the task, maintain his behavior while working, ensure that he completes the task properly in accordance with the objectives and willing to make improvement if it is necessary [11]. Different opinions were expressed by Schaufeli and Bakker, Rothbard in Saks, who define that: "Engagement as a further psychological involvement comprises of two important components that are attention and absorption [12]. Attention refers to the availability of cognitive and total time dedicated by an employee in thinking and carrying out his role, while Absorption is how an employee interpret the role and put a intense focus on the role in the organization.

Based on several definitions put forward by some experts, it can be concluded that employee engagement is a sense of belonging and involvement of an employee to his organization that make him be able to do something beyond his ability, to give his best performance to achieve organizational goals.

\section{Research Methodology}

Based on the theory description, problem statement and the research hypothesis, the objectives of this study are to analyze, review and understand the following:

1) Organizational Culture $\left(X_{1}\right)$ has a positive direct effect on employee engagement $(Y)$.

2) Leadership $\left(\mathrm{X}_{2}\right)$ has a positive direct effect on employee engagement (Y).

Based on the hyphothectical model mentioned above, it can be define 2 (two) statistic hypothesis that will be validated in this research that are:

1) $\quad \mathrm{H}_{\mathrm{o}}: \beta_{\mathrm{y} 1} \leq 0$

$\mathrm{H}_{1}: \beta_{\mathrm{y} 1}>0$ 
Note:

$$
\mathrm{H}_{1}: \beta_{\mathrm{y} 2}>0
$$

$\mathrm{H}_{0}:$ Null Hypothesis

$\mathrm{H}_{1}$ : Alternative Hypothesis

$\beta_{\mathrm{y} 1}$ : Path coefficient variable $\mathrm{X}_{1}$ that has a direct effect on variable $\mathrm{Y}$

$\beta_{y 2}$ : Path Coefficient variable $X_{2}$ that has a direct impact on variable $Y$

\section{Research Result}

\subsection{Analysis Requirement Test}

Requirements testing that include the estimated normality error test and linearity test and significance test are carried out before hypothesis test. To test the hypothesis, several requirements must be fulfilled. Those requirements are: 1) samples must be taken randomly, 2) Error data and estimation of each variable is normality distributed and 3) Form of regression is large and significant.

The requirements test that is used is the estimated error normality test $(\mathrm{Xi}-\mathrm{Xj})$ from a simple regression and linearity requirement for each relationship ( $\mathrm{Y}$ on $\mathrm{X}_{1}, \mathrm{Y}$ on $\mathrm{X}_{2}$ ). Hypothesis testing can be done if the sample is normally distributed.

\subsection{Normality Test}

Normality test is the first testing requirement, that is an estimation error. The test for this normality requirement is made a relationship $\left(\mathrm{Y}\right.$ on $\mathrm{X}_{1}, \mathrm{Y}$ on $\left.\mathrm{X}_{2}\right)$. By using the Lilliefors formula. The normality test criteria is to accept the null hypothesis (HO) is normally distributed. The sample will be normally distributed if the results obtained with Lcounted (Lo) $<$ Ltable (Lt) on the list of critical $\mathrm{L}$ values for $\mathrm{n}=399$ with a real level $\alpha=0.05$. On the other hand, while the results of the estimated error normality test can be seen in Appendix two and a summary of the results of the data normality test performed for estimated errors is in the following table

Table 1. Recapitulation of Data Normality Test Results for Estimated Errors

\begin{tabular}{clccc}
\hline No & \multicolumn{1}{c}{ Variable } & Test Statistic & Conclusion & Interpretation \\
\hline 1 & Organizational Culture $\left(\mathrm{X}_{1}\right)$ & 0.063 & $\mathrm{H}_{0}$ accepted & Normal \\
2 & Leadership $\left(\mathrm{X}_{2}\right)$ & 0.066 & $\mathrm{H}_{0}$ accepted & Normal \\
3 & Employee Engagement $(\mathrm{Y})$ & 0.076 & $\mathrm{H}_{0}$ accepted & Normal \\
\hline
\end{tabular}

From the table above, it shows that the data meets the normality assumption by looking at the test statistic where the sample will be normally distributed if the probability is $>0.05$ then $\mathrm{H} 0$ is accepted but the population distribution is not normal if the probability is $\leq 0.05$ then $\mathrm{H} 0$ is rejected. Thus it means that the distribution of Employee Engagement (Y), Organizational Culture $\left(\mathrm{X}_{1}\right)$, Leadership $\left(\mathrm{X}_{2}\right)$, Job Satisfaction $\left(\mathrm{X}_{3}\right)$, is a dispersion of normally distributed populations. 


\subsection{Significance test and linearity of the regression model}

The last requirement that must be fulfilled in conducting path analysis is the variables formulated in the structural model have a significant and linear relationship. Therefore, the significance and linearity of simple linear regression models in the table tested as follows:

Table 2. Significant Test Result Summary

\begin{tabular}{lllll}
\hline No & Regression Model & F amount & $\begin{array}{l}\text { F tabel } \\
(\text { alpha=0.05) }\end{array}$ & Conclusion \\
\hline 1 & Y on $\mathrm{X}_{1}$ & 746.6 & 3.86 & Significant \\
2 & Y on $\mathrm{X}_{2}$ & 683.91 & 3.86 & Significant \\
\hline
\end{tabular}

Table 3. Linearity Test Result Summary

\begin{tabular}{lllll}
\hline No & Regression Model & $\mathrm{F}_{\text {hitung }}$ & $\begin{array}{l}\mathrm{F}_{\text {tabel }} \\
(\mathrm{alpha}=0.05)\end{array}$ & Conclusion \\
\hline 1 & ${\mathrm{Y} \text { on } \mathrm{X}_{1}}_{2}$ & .352 & 1.32 & Linear \\
& ${\mathrm{Y} \mathrm{on} \mathrm{X}_{2}}$ & .852 & 1.32 & Linear \\
\hline
\end{tabular}

\subsection{Hypothesis Test}

Path coefficient that is analyzed according to the research hypothesis are $\rho y_{1}, \rho y_{2}$. Calculation of Substructure path coefficien for positive influence of organizational culture $\left(\mathrm{X}_{1}\right)$, leadership $\left(\mathrm{X}_{2}\right)$, on employee engagement $(\mathrm{Y})$. Calculation results of the calculation of the Substructure II coefficient can be seen in Table 4.

Table 4. Hypothesis Testing Results Structure Equation Model 1 Summary:

\begin{tabular}{cccccc}
\hline \multicolumn{7}{c}{ Coefficients } \\
\hline Model & Unstandarized Coefficients & $\begin{array}{c}\text { Standardized } \\
\text { Coefficients } \\
\text { Beta }\end{array}$ & T & Sig. \\
\hline B & Std. Error & 3.528 & & 1.649 & .100 \\
$\mathrm{X}_{1}$ & .190 & .057 & .181 & 3.342 & .001 \\
$\mathrm{X}_{2}$ & .659 & .056 & .633 & 11.696 & .000 \\
\hline
\end{tabular}

Based on the calculation and testing of path coefficients, it is obtained the results of calculations and testing that is the influence between variables as follows: (1) organizational culture $\left(\mathrm{X}_{1}\right)$ has a positive direct effect on employee engagement $(\mathrm{Y})$, obtained py 1 path coefficient of 0.181 with $t_{\text {count }}$ of 3.342 , while ttable equal to $1.97(\alpha=0.05)$, because $t_{\text {counted }}>$ $t_{\text {table }}(\alpha=0.05)$, then $H_{0}$ is rejected. The hypothesis test result indicates that there is a positive direct effect of Organizational culture $\left(\mathrm{X}_{1}\right)$ on employee enggagement (Y). (2) Leadership $\left(\mathrm{X}_{2}\right)$ has a positive direct effect on employee enggagement $(\mathrm{Y})$, the py 2 path coefficient is 0.633 with a $t_{\text {count }}$ of 11.696 , while $t$ table is 1.97 at $\alpha=0.05$, because $t_{\text {count }}>t_{\text {table }}(\alpha=0,05)$, then $\mathrm{H}_{0}$ is rejected. The hypothesis test result indicates that there is a positive direct effect of Leadership $\left(\mathrm{X}_{2}\right)$ on employee enggagement $(\mathrm{Y})$. 


\subsection{Anaysis}

The discussion of the study is as follows: (1) Organizational culture has a positive effect on Employee Engagement. Thus, the better the Organizational Culture, the higher Employee Engagement will be. This means the hypothesis is valid. (2) Leadership has a positive effect on Employee Engagement. Thus, when there is an increase in the leadership at PT BNI Life, it will result in an increase of Employee Engagement. This means the hypothesis is valid.

\section{Conclusion}

Based on the findings above, it can be concluded that (1) Organizational culture has a positive direct effect on employee engagement. That is, an increase in organizational culture will result in an increase in employee engagements. (2) Leadership has a direct positive effect on employee engagement. That is, an increase leadership will result in an increase in Employee Engagement.

\section{References}

[1] Ivancevich, et. all. Organization. New York: McGraw-Hill, 2009.

[2] Greenberg, Jerald dan Robert Baron. Behavior in Organizations ( understanding and managing the human side of work ). Eight edition, Prentice Hall, 2003.

[3] Schneider, A.A. Personal Adjustment and Mental Health. New York: Holtt. Renehart and Winston Inc, 2008.

[4] Colquitt, Jason A., Jeffery A. Lepine, Michael J. Wesson. Organizational Behavior. New York: McGraw - Hill/Irwin, 2009.

[5] Wibowo, Manajemen Kinerja. Jakarta: Rajawali Pers, 2010.

[6] Ivancevich, et. all. Organization. New York: McGraw-Hill, 2009.

[7] Schein, Edgar. Organizational Culture and Leadership, Third Edition.CA : JosseyBass, San Francisco, 2004.

[8] Goetsch, David L dan Stanley B. Davis. Quality Management. New Jersey: Prentice Hall, 2000.

[9] Albrecht, S, Handbook of Employee Engagement : Perspectives, Issues, Research and Practice. UK : Edward Elgar Publishing, 2010

[10] Federman, Bard, Employee Engagement: A Road For Creating Profits, Optimizing Perfomance, And Increasing Loyalty. San Fransisco: Josey Bass, 2009.

[11] Marciano, Paul L, Carrots and Stichs Don't Work Build a Culture of Employee Engagement with the Principles of Respect. Mexico: Mc.Graw Hill, 2010.

[12] Saks, A.M, Antecedents And Consequences Of Employee Engagement. Journal of Managerial Psychology Vol. 21 No. 7, 2006. 